\title{
Interview with Patricia Hill Collins on Critical Thinking, Intersectionality and Educational: key objectives for critical articulation on Inclusive Education
}

\author{
Aldo Ocampo González \\ Center for Latin American Studies of Inclusive Education (CELEI), Santiago de \\ Chile
}

\section{Patricia Hill Collins}

University of Maryland, College Park, Maryland, USA

\section{Abstract}

The interview with Patricia Hill Collins, a prominent social theorist whose research and studies have examined issues of race, gender, social class, sexuality and / or nation, make her a significant reference in the field of Education and Intersectionality. The content of this interview can be described in Deleuzian and Guattarian terms as crucial elements in the configuration of a Pedagogy of the minor, that is, centered on the multiplicity of differences that inhabit the school space, of which semiological, citizen and political force demand the reconfiguration of the school space. In such a case, Inclusive Education involves a complex change in the way of thinking and practicing a variety of problems and issues that relate to the totality of students known as multiple singularities. Hill Collins thinks that intersectionality is seen as a form of research and critical practice that academics and activists have used to develop a more complex understanding of social inequality and social injustice, emerging in many places by people who dealt with the common social 
problem to respond to social injustice. The construction of a public education through the lens of inclusion demands the building positive labor - of an educational architecture capable of critically examining issues related to race, schools, the common benefit and democratic possibilities, recognizing the endemic nature of the violence. All this suggests a change of paradigm in the way in which intersection power systems inform the structures and organizational practices of schools. A public education system adheres to broader ethical principles of equity, equality, justice and inclusion. Thereby assuming, as a complex, relational, structural and multidimensional term. Countering the effects of differential inclusion, that is, through inequalities, proposes the challenge to educational systems to address the production of socially unfair results through education as a mechanism to reproduce inequality. American social theory points out that it is vital to offer an understanding of social justice in a more complex way to address educational inequalities. The interview addresses topics related to social and educational justice, the contribution of feminism as critical elements in the construction of the epistemology of Inclusive Education, the contributions of the intersectional current as a heuristic and methodological device key in the examination of law in the education of the infinite multiplicity of differences.

Keywords: intersectionality, inclusive education, educational justice, other public education. 


\section{Bionota:}

\section{Dr. Patricia Hill Collins}

Professor Collins is a social theorist whose research and scholarship have examined issues of race, gender, social class, sexuality and/or nation. Her first book, Black Feminist Thought: Knowledge, Consciousness, and the Politics of Empowerment (Routledge), published in 1990, with a revised tenth year anniversary edition published in 2000, won the Jessie Bernard Award of the American Sociological Association (ASA) for significant scholarship in gender, and the C. Wright Mills Award of the Society for the Study of Social Problems. Her second book, Race, Class, and Gender: An Anthology, 8th ed. (2013), edited with Margaret Andersen, is widely used in undergraduate classrooms in over 200 colleges and universities. Black Sexual Politics: African Americans, Gender, and the New Racism (Routledge, 2004) received ASA's 2007 Distinguished Publication Award. Her other books include Fighting Words: Black Women and the Search for Justice (University of Minnesota Press, 1998); From Black Power to Hip Hop: Racism, Nationalism, and Feminism (Temple University Press 2005); Another Kind of Public Education: Race, Schools, the Media and Democratic Possibilities (Beacon Press, 2009); the Handbook of Race and Ethnic Studies, edited with John Solomos (Sage, 2010); and On Intellectual Activism (Temple University Press, 2012). She has published many articles in professional journals such as the Journal of Speculative Philosophy, Qualitative Sociology, Ethnic and Racial Studies, the American Sociological Review, Signs, Sociological Theory, Social Problems, and Black Scholar, as well as in edited volumes. Professor Collins has taught at several institutions, held editorial positions with professional journals, lectured widely in the United States and abroad, served in many capacities in professional organizations, and has acted as consultant for a number of businesses and community organizations. In 2008, she became the 100th President of the American 
Sociological Association, the first African American woman elected to this position in the organization's then 104-year history. Professor Collins also holds an appointment as the Charles Phelps Taft Emeritus Professor of Sociology within the Department of African American Studies at the University of Cincinnati. Professor Collins's current research interests lie in the following sociology of knowledge projects: (1) the epistemology of intersectionality, specifically, analyzing how race, class, gender, sexuality, ethnicity, nation and/or age mutually construct one another as systems of power and as theoretical constructs; (3) exploring epistemologies of emancipatory knowledges, for example, critical race theory, nationalism and feminism; and (3) examining how African American male and female youth's experiences with social issues of education, unemployment, popular culture and political activism articulate with global phenomena, specifically, complex social inequalities, global capitalist development, transnationalism, and political activism.

A.O.G.: Good afternoon Dr. Hill Collins, we would like to thank you for your support and willingness to participate in this cycle of interviews.

You are considered one of the most important social theorists in North America. According to this, ¿what is your conception of intersectionality? ¿what analytical-methodological elements allow us to understand intersectionality as a critical social theory?

P.H.C.: I see intersectionality as a form of critical inquiry and practice that scholars and activists have used to develop more complex understandings of social inequality and social injustice. In the United States, the idea of intersectionality became increasingly visible in the context of mid-twentieth 
century social justice movements for race, gender, class and sexuality. Within this context, African American women were central both to developing intersectionality as a concept as well as making intersectionality visible (see, e.g., Collins 2000). But it is important to emphasize that intersectionality neither originated in the minds of individual activists or scholars, nor is it the intellectual property of any one group. Intersectionality is not necessarily a North American or Western construct. Instead, intersectionality bubbled up in many places by people who grappled with the common social problem of responding to social injustice. Because we haven't examined intersectionality beyond this particular history, we know far less about its contours in the Global South.

In the $1990 \mathrm{~s}$, the term intersectionality was increasingly taken up in the U.S. to name this emerging perspective on inequality. Many groups that had grappled with similar social problems through race-only or gender-only frameworks recognized that their own projects could be strengthened via collaboration with one another. Ongoing projects to examine how race and gender, for example, might inform a shared social problem or social concern, became increasingly common. Intersectionality, a book that I co-authored volume with Sirma Bilge, provides a preliminary mapping of the broad spread of intersectionality's ideas as well as the ever-expanding scope of its practice (Collins and Bilge 2016). We treat intersectionality as an important key concept for analyzing contemporary social phenomena. ${ }^{\text {ii }}$ Because scholars and activists alike have used intersectionality for a variety of projects, the varying ways that people use intersectionality reflects diverse intellectual and political projects. Stated differently, using intersectionality is not politically neutral and, as a result, intersectionality is not finished but is a work-in-progress. 
Substantively, intersectionality focuses on systems of power. Some approaches to intersectionality describe race, class, gender and sexuality as variables in a given study or as attributes of individual identity. My approach to intersectionality places power relations themselves squarely in the center of analysis, often as a way to develop more complex explanations for specific topics of investigation. To me, intersectionality provides an important analytical lens for developing more substantive analyses of social problems such as violence, illiteracy, and poverty as well as for social inequality itself. In contrast, because violence has been so heavily implicated in sustaining social injustice, the ways in which intersecting power relations inform varying expressions of violence has been a major theme within intersectional scholarship. At the same time, because violence is endemic to varying systems of power, intersectional analyses of violence shed light on how systems of power mutually construct one another. One guiding premise of intersectional analysis is that race, class, gender and sexuality as systems of power have interactive effects. In other words, not only do these systems of power mutually construct one another, the power relations that they engender gain meaning from each other. In this sense, intersectionality has criticized existing knowledge on a host of topics and catalyzed new questions and interpretations.

Despite its reach and obvious importance, I think that it is premature to conclude that intersectionality is already the critical social theory that people assume it to be. Rather than approaching intersectionality as a "finished" critical social theory, and then criticizing it accordingly, I think that intersectionality is better served by seeing it as a critical social theory that is under construction. But what does this mean? And how do we go about "constructing" intersectionality as a critical social theory? 
My latest book, Not Just Ideas: Intersectionality as Critical Social Theory, takes up these questions. In it, I analyze how people use intersectionality as a way of examining its theoretical contours (Collins forthcoming). To build an argument about critical social theory, I examine how academics and activists alike use intersectionality as a metaphor, as a heuristic device and as a paradigm. The idea of intersectionality draws from the metaphor of a crossroads, or meeting place where analyses that have been on separate paths can converge and learn from one another. Intersectionality as metaphor travels easily between academic and activist settings, thereby accounting for why so many different people use the same term for so many different kinds of projects. Others use intersectionality as a heuristic or a rule of thumb common sense approach to problem solving. This heuristic use accounts for its use across many disciplines, and explains why, for example, scholars and activists alike find it useful for deepening their understandings of specific topics. Intersectionality has also fostered a paradigm shift in how we think about a range of topics. For example, intersectionality fosters a paradigm shift within education by seeing students and teachers as having intersecting identities that shape their classroom experiences. It also suggests a paradigm shift in how intersecting systems of power inform the structures and organizational practices of schools.

These multiple uses lay the foundation for intersectionality as a critical social theory, but they are no substitute for social theory. Part of intersectionality's resiliency stems from its open-ended nature that enables people to use it in different ways for multiple projects. This shift makes critical theorizing as a process more central to intersectionality than critical social theory as a product. For intersectionality to become a critical social theory, its practitioners need to examine its guiding questions, content, methodological approaches and ethical underpinnings. I take up these issues in Not Just Ideas, not to prematurely 
celebrate intersectionality for its arrival as a critical social theory or to castigate intersectionality for being an inadequate social theory. Instead, in Not Just Ideas, I invite those who claim intersectionality for various scholarly and activist projects into a broader conversation about this very question of intersectionality's theoretical future. In short, I see intersectionality as a critical social theory in the making.

A.O.G.: Considering the transcendence of the intersectional current, iwhat could be, in your opinion, the methodological options that this proposal expresses to investigate the performative and regenerative nature of power and, in particular, of exclusion?

P.H.C.: One premise of intersectionality is that intersectional analyses are somehow superior to mono-categorical analyses of power relations. In other words, a race/gender analysis will be somehow better than one that focuses on race or gender alone. But how would one support this claim? One approach that I have taken is to identify specific issues or themes that reappear across separate systems of power and examine how they might work together. For example, in my earlier work, I examine how families and intersectionality are interconnected. Intersectionality provides a framework for understanding the significance of family from one society to the next. Conversely, because it is a universal social institution, the construct of family provides a window into intersectionality. (Collins 1998a; Collins 2017). Similarly, violence constitutes an important social issue for scholars and activists alike. Intersectionality provides a more robust lens for seeing how particular intersections organize violence as a meaningful set of ideas and practices within a particular social setting (Collins 1998b). For example, broadening analysis of violence against women beyond a gender-only lens brings texture and nuance to the myriad 
expressions of gendered violence against women, men and gender nonconforming people. Women are not monolithic, and based on intersections of gender, sexuality, class, race and citizenship status, they encounter different forms of violence. In essence, domestic violence, hate crimes, state-sanctioned, extra-judicial killings, vigilante justice, sexual harassment in the workplace, child abuse and similar expressions of violence are not simply discrete events, but are interconnected.

But there's a bigger theoretical issue here than the utility of intersectionality for social problem solving (e.g., its heuristic use). The domination that underpins race, class, gender, and sexuality as systems of power routinely rely on force or the threat of force. Yet they rely on noticeably different expressions of violence - the intimate partner violence of gender oppression as compared to the statesanctioned violence of racism. In this sense, violence operates as a kind of conceptual glue that works to bind various forms of oppression together.

In essence, rather than trying to theorize methodology in the abstract, my methodological approach has been to identify empirical challenges in the social world and to see how an intersectional framework might inform them and, conversely, how they might inform theories of power. This in turn fosters selfreflexivity concerning methodology and praxis.

A.O.G.: In one of your books, you raise the need to build another type of public education, ¿what are the main critical points that allow you to affirm this?, $¿$ what should be the public education that you propose?, and, finally, ¿what are the possibilities for democracy, social justice and inclusion, from the functioning and organization of schools in this new type of public education? 
P.H.C.: My approach to public education is quite simple - we need a public that is informed and that shares a common commitment to some notion of the common good. A quality public education also aims to cultivate a knowledgeable public that holds fast to broader ethical principles of equity and fairness. But an educated public requires not just information, but also skills of critical thinking that enable its members to make informed decisions. A good public education equips people with skills of critical analysis so that they can tell the difference between so-called fake news and reputable professional journalism. This kind of educated public must cultivate a sense of selfreflexivity so that it can assess how well public officials contribute to the public good.

Public schools lie at the heart of democratic participation. As a former classroom teacher in underfunded schools, I know how hard it is to provide a quality education for children and teenagers in substandard buildings and without basic supplies. But education is far broader than formal schooling. Parents, grandmothers, physicians, siblings, shopkeepers, community workers, activists, religious personnel, elected officials, spoken word poets, corporate sponsors, and NGO staff and many others make different contributions to the public education of subsequent generations. Young people are the future citizens of our societies. As such, they encounter the harsh lessons of unequal citizenship as part of their lives. It would be nice if all children and youth could attend well-funded schools with skilled, caring and well-paid teachers. That hasn't happened yet and for many, it's unlikely to happen in the near future.

At the same time, youth also see possibilities that many adults overlook or cannot imagine. Critical thinking is the bedrock of critical education and youth are far more likely to ask the difficult, uncomfortable questions that adults 
avoid. Youth constantly learn, and they learn different things from a variety of people. To me, good pedagogy matters, regardless of where it occurs and who does the teaching. While schools are important, they are not the only site for critical education. The strategies or institutional foundations of such a public education need not be in schools. New communications technologies and the Internet have changed so much about how we get information, how we assess (or not) the information and arguments that appear online, and a sense of belonging to something that comes close to being a public good.

When I revisit my prior writings, I find myself moving away from my use of the term public. The term public increasingly feels like an analytical category that academics and politicians apply to a social reality that does not reflect the lives of everyday people. The rhetoric of democracy remains in place, yet the reality of the erosion of democratic institutions leaves many people alienated from the public institutions that allegedly serve them. It seems that democracies have moved away from being concerned with the public writ large, serving a portion of the public that they seemingly represent. The recent growth of right-wing populism in the United States, Brazil and Hungary among other nations suggests that this ambiguous use of the public as proxy for a democratic public is not necessarily beneficial to all. Academics often assume that the public good within democracies is served when everyday people identify themselves as part of a public. Submerging oneself in the public and supporting policies that seemingly advance the public good are more desirable that a public that pulls in opposite directions.

One minor thread throughout my work has been attention to the construct of community (Collins 2010). In contrast to the term public, the idea of community provides a more malleable way to talk about social groups and collectivities. Whether neighborhoods, church groups, academic departments or broader 
imagined communities of nation-states, the notion of community speaks more strongly to me as a term that organizes power relations. As individuals, we don't necessarily see the public as the social unit to which we belong. Instead, as individuals, we navigate our ties to multiple communities, for example, those of our families, neighborhoods, religious groups, civic organizations and sports teams. Gender, race, class and sexuality become submerged within notions of a public, yet these same systems are organized through multiple communities. These communities provide a language for understanding our location in power relations as well a site that better explains our place in an abstract notion of the public.

When I look back on the trajectory of my career in education, much of it attending public schools as a child or working in public institutions of higher education throughout my career, I am devoted to creating quality public institutions that serve us all. At the same time, we need an analysis of the collective that can handle the kind of public education that I have in mind. And for me, the language of community, one that resonates with people on the bottom, may be especially useful in bringing about another kind of public education.

A.O.G.: Considering the relevance of your intellectual work, ¿what would be, in your opinion, the most revolutionary legacies and contributions that feminism contributes - as a field of research and political action- to the creation of an epistemology of Inclusive Education?

P.H.C.: I think that feminism has the potential to be extremely radical, if it recognizes the power of women's work in sustaining families and communities. Feminism must do a better job of cultivating the radical potential of what 
women can and already do in their everyday lives as sisters, mothers, teachers, daughters and wives. Changes and public policies and workplace conditions in the public sphere to make them more amenable to women are extremely important. But radical change in two institutions that touch all women, the socalled private sphere institutions of families and communities, is equally if not more significant.

Women's rights is a core premise of global feminism, and these rights rest on the bedrock of individual freedom. In this sense, Western feminism does a good job of arguing for individuality and for freedom for individual women. Feminism criticizes gender discrimination in the public sphere, pointing to all the ways that women are treated as second-class citizens. Feminism has also criticized the treatment of women within families and communities, pointing out all the ways that custom and tradition work to subordinate women. One outcome of this framework is that feminist analyses of women's oppression identify families and communities as important sites of women's oppression. And if families and communities are sites of women's oppression, then feminism should aim to free women from these relationships.

But is it really as simple as this? For African American women, indigenous women and women who are similarly subordinated, politics encompasses a broad constellation of behaviors. Families and communities have often been the protection against racism, colonialism and economic exploitation. Responding to the specific challenges of these systems has catalyzed forms of feminism among racial-ethnic women and indigenous women that has stimulated new knowledge (intersectionality) as well as new forms of political activism (a survival politics as well as a politics of protest). For example, working within families and communities for women's empowerment has been the bedrock of 
U.S. Black feminism, a form of politics that never precluded pushing for changes in the public sphere. Many prominent Black feminists have done both - they have used their status as women within African communities to push for change within such communities and, as individuals, they have also advocated for their communities in the public sphere.

Black communities and similarly subordinated communities raise important questions for feminism. How can a woman be a "feminist" and connected to a collectivity that may oppress her at the same time? Black feminism in the United States grapples with these contradictions; how does one both express the aspirations of individual African American women and advance the needs of Black people as a collectivity? Can an individual Black woman ever be free without all members of the Black community also gaining their freedom?

When feminism derogates what it sees as women's work, it misrecognizes political action and political possibilities by women who seemingly fall outside of accepted feminist politics. This myopia in turn advances a partial understanding of women's political action. It seems that protest politics, which more closely resemble the behavior of men, is elevated above that of women. Feminism is an important form of protest politics that occurs when an individual woman claims a "feminist" identity and then engages in visible political protest in the public sphere. Feminist activism results in the accumulation of individuals who claim such identities pushing for women's rights. For many women, especially Western women, this trajectory rings true.

But just as there are multiple paths to intersectionality, there are also many paths to feminism. Feminism is at its best when it recognizes and cultivates this heterogeneity. The issue of a feminism that is focused on children and family 
and building community capacity is often foundational to Black feminism and indigenous feminism, in part because this is the basis of indigenous life, and in part, this stance is necessary as a strategy of resistance for survival politics. Making sure that the next generation survives and, if possible, thrives is part of a feminist agenda. But just as women are differentially positioned, so too are the expressions of this version of feminism.

When it comes to the radical nature of feminism and its connections to inclusive education, what can be more radical than teaching children and youth that they are loved in societies that routinely reject them? What can be more radical than believing that another world is possible for one's children in the face of a world that tells them that it is not? What can be more radical than touching and changing lives, stimulating imaginations, and watching as young people create possibilities from the seemingly impossible?

A.O.G.: Since its conception, what progress and / or limitations does it express the construction of social justice, the right to difference and a fairer education in the first years of the 21st century?, ¿what should be the key axes for the strengthening of a critically subversive social justice and equity policy in education for the new century?

P.H.C.: The relationship between social justice and educational equity is an extremely broad topic. What I can do is identify several themes that might contribute to a discussion on this topic. For one, it is important to recognize how different populations who are differentially situated within power relations of gender, race, ethnicity, class and sexuality have differential access to formal education. Basic access to schools is fundamental. I'm thinking here of how some societies educate girls whereas others don't send them to school. When 
girls are not valued within a society, why educate them? Poor children face similar barriers. Many never attend school because they have to work. Racial, ethnic and religious intolerance have also been powerful forces in denying formal education to children and youth. Access to basic education is crucial to a society's success but educating girls, poor children and/or racial-ethnic youth is not often seen as vital to a soicety's future.

Beyond this question of basic access, there's the issue of the quality of education that different groups receive. Because I am a college professor, I'll use an example from higher education, but the same issue applies on all levels of formal education. In the United States, the category of "college students" seemingly captures the experiences of people who attend college. For me, however, this term obscures more than it reveals. I've visited so many colleges and met so many different kinds of students that I don't believe that there is any such thing as a generic "college student." Within that one category lies a vast inequality not only in basic access to education but also the quality of educational offerings. Some students attend elite institutions where they benefit from small classes, excellent libraries, easy access to broadband internet, and exposure highly trained faculty who take the time to get to know them and personalize their education. Other students attend large public universities and community colleges where they encounter overly-large classes, rationed digital services that make it difficult complete assignments, and faculty who are simply stretched too thin to spend time with them. Still other students rely on distance learning, rarely setting foot in a college classroom or engaging in face-to-face discussions with faculty members or their peers. Unsurprisingly, these different pathways through college foster differential outcomes for students when they leave, hopefully with a degree in hand, but far too often with unsustainable debt. 
Basically, when we use this term "college student," we can each imagine a unique archetypal individual with a given race, class, gender, sexuality, age, class, ability and ethnic/religious affiliation that matches our idiosyncratic experiences. We may use the same language when we communicate but imagine someone quite different. Because this blanket term masks social inequalities, it leaves us unprepared to deal with the social injustices of educational inequality. Uncritically using the term "college student" ignores the widespread educational inequality that leaves some students blissfully unaware of the struggles of women, poor people and racial-ethnic groups, and other students woefully uninformed about the quality of their own formal education. Basically, the myth that attending college is the great equalizer works to obscure how education is pivotal in producing social inequality. It is both a cause and a solution to educational inequality. How do you do about solving a problem that you don't think exists?

When it comes to addressing educational inequity, we need first to recognize how structural inequalities within society shape access to and the quality of educational institutions as well how structural inequities within education articulate with gender, class, race and similar broader categories of social inequality. On a basic level, different groups have differential access to formal education, and this in turn shapes their status in society. For another, different populations have different educational needs and experiences with formal educational institutions. On a societal level, educational equity reflects the needs of a given population within a nation-state. Various intersections of gender, race, age, ethnicity, class, citizenship status, sexuality and ability articulate with these categories of learners within the category "college student." For example, while girls in a given society may be denied education, girls from elite families often receive more education than their less fortunate, 
poorer counterparts. In this way, systems of power produce socially unjust outcomes via education as a mechanism for reproducing inequality.

Social justice can be a touchstone for remedying social inequalities, primarily because it argues in favor of fairness. Small children intuitively recognize what is fair and what is not. They notice when a cookie is divided into two parts where one portion is clearly bigger than the other. If the children are in fact equal, shouldn't each receive an equal portion? But fairness is not always sameness. When one child is on the autism spectrum and the other is not, should they be treated differently in order to achieve fairness? Understandings of fairness and social justice are learned in everyday educational situations. This has implications for developing more complex understandings of social justice that see education as simultaneously the cause and solution to social inequality.

We must put social justice to work in solving particular social problems, not relegate it to the terrain of social theory where its contours can be endlessly debated without consequences. Educational equity is not simply a free-floating, abstract concept but has tangible, longlasting effects throughout our lives. Holding fast to more complex understandings of social justice is essential in addressing educational inequities. I would encourage us to think more expansively about social justice as an ethical concept that is not simply an optional add-on dimension of an existing educational project, but rather as a construct that is fundamental to everything we think and do.

Social justice is an inherently aspirational and relational concept. It is aspirational is that there is no way of achieving a socially just society, at least not one that I can envision in the lifetime of my grandchildren, but rather is a touchstone for contemporary practice. Social justice may not be achievable as a 
goal, but it is a worthwhile goal to pursue. Social justice is also relational because the relationships among gender, class, race and sexuality as systems of power catalyze ever-changing patterns of social injustice. We have to assume that society is unjust and characterized by social injustice. This means that we also have to examine our relationship to social injustice and our own actions and/or inactions in relation to it. Each of us faces a fundamental existential question -- when it comes to social justice, are we part of the problem or part of the solution?

\section{References}

Collins, Patricia Hill. (1998a). "It's All in the Family: Intersections of Gender, Race, and Nation." Hypatia 13(3):62-82.

Collins, Patricia Hill. (1998b). "The Tie That Binds: Race, Gender and U.S. Violence." Ethnic and Racial Studies 21(5): 918-38.

Collins, Patricia Hill. ( 2000). Black Feminist Thought: Knowledge, Consciousness, and the Politics of Empowerment. New York: Routledge.

Collins, Patricia Hill. (2010). "The New Politics of Community" American Sociological Review 75(1):7-30.

Collins, Patricia Hill. (2017). "On Violence, Intersectionality and Transversal Politics." Ethnic and Racial Studies 40(9):1-14.

Collins, Patricia Hill. (2017). forthcoming. Not Just Ideas: Intersectionality, Critical Theory and Social Change. Durham, NC: Duke University Press.

Collins, Patricia Hill. (2019). Intersectionality as Critical Social Theory. Durham, NC: Duke University Press.

Collins, Patricia Hill, and Sirma Bilge. (2016). Intersectionality. Cambridge, UK: Polity.

\section{Notes}

\footnotetext{
${ }^{i}$ Director Center for Latin American Studies of Inclusive Education (CELEI), Santiago de Chile. First research center created in Latin America and the Caribbean and in Chile, for the theoretical and methodological study of Inclusive Education. Articulates his investigative and formative work from an inter, post and para-disciplinary. Center member of the Latin American Council of Social Sciences (CLACSO).
} 


\section{Authors Details}

Aldo Ocampo González is Director at Center for Latin American Studies of Inclusive Education (CELEI), Santiago de Chile, Chile.

Patricia Hill Collins is a Distinguished University Professor of Sociology at the University of Maryland, College Park, Maryland, USA. 